\title{
A Research on the Financial Models of Wuhan Rail Transit
}

\author{
Meng $\mathrm{Li}^{1, \mathrm{a}}$ \\ ${ }^{1}$ School of economics and management, Beijing jiaotong University, Beijing, China \\ a710971248@qq.com
}

\begin{abstract}
Keywords: Wuhan Metro • Financing • Sustainability
Abstract. Wuhan Metro, also known as Wuhan Rail Transit, is the urban rail transportation system of Wuhan City. From the subsequences of other cities' metro construction and operating conditions, it is obvious that the project investment is huge and the construction is costly; the project is burning a huge sum of money in the construction and initial operation period; raising money is difficult because of the low rate of return compared to that huge investment. There will inevitably be problems in Wuhan rail transportation system since the city is a novice in the rail constructions and definitely has lack of experience to ensure the successful construction and on-time delivery of the follow-up subway lines in Wuhan, it is necessary to sort out the existing financing models and summarize some lessons to guide the next stage of Wuhan City metro construction and operation.
\end{abstract}

\section{Introduction}

The urban rail transportation system is a large public transport infrastructure, which costs a largescale of funds, has a long construction period, and affects a wide range of beneficiaries. The construction and operation of Metro involves all aspects of society, therefore, to study the city track transportation financing problem, we must begin with its economic attributes.

Positive externalities. As a quasi public goods, the subway has strong positive externalities, which is mainly reflected in the following aspects: The subway will improve the quality of city resident travelling, greatly reducing traffic waiting time and the adverse effects the city traffic congestion brings; The subway can attract a large number of passengers, which effectively alleviates the traffic pressure; The subway can effectively reduce the use of land, energy, and reduce environmental pollution in city, which is conducive to environmental protection. The entire transport network can carry a larger number of metro traffic passengers whose resources are relatively stable, which is conducive to the development of land along, enhances the value of land, and promotes the development of other industries.

Positive externalities economies of scale. Metro has a characteristic of a large economic scale, which mainly lies in the following four points: First, the construction of the subway network needs large scale of investment, a long construction period, high asset specificity, high sunk cost. At the same time, once the subway is completed, equipment depreciation period is long, the durability is high, so the subway is the marginal cost is very low. Therefore, the more the passengers, the more obvious the effect of scale economy is; Second, any service provided by the subway line network is based on the scale and the overall level of network. More intensive, covering more area, more convenient, more passengers, the higher efficiency. In general, the subway is limited to the size of the lowest efficiency, but the efficiency from economic scale is increasing.

\section{Current situation of Wuhan Rail Transit Financing Model}

Wuhan urban rail transit construction plan for $2014-2020^{[1]}$ : building 439.1 kilometers of track traffic network system in 2020, including 15 new or extended lines covering a total length of 226.9 kilometers, 178.1 kilometers of which is under the ground, 1.7 kilometers is on the ground, Overhead lines are 47.1. According to Wuhan City Metro Group's official website and "Wuhan City Metro Group Co., the corporate bond prospectus", the plan of the specific lines and investment by the end of 2020 as shown below: 
Table 1. The construction scheme of the list.

\begin{tabular}{lrc}
\hline The name of the line & $\begin{array}{c}\text { Line length } \\
\text { [kilometer] }\end{array}$ & $\begin{array}{c}\text { (quasi)investment } \\
\text { [100 million yuan] }\end{array}$ \\
\hline Line 1 & 28.50 & 91.49 \\
Line 2 the first phase & 27.70 & 154.57 \\
Line 4 the first phase & 16.50 & 95.66 \\
Extension of Line 1 & 1.20 & 15.00 \\
South extension of line 2 & 5.80 & 101.77 \\
Line 3 a phase & 27.90 & 202.10 \\
Line 4 in the two period & 16.70 & 112.30 \\
Line 6 the first phase & 36.00 & 267.40 \\
Line 7 the first phase & 30.90 & 179.50 \\
Line 8 the first phase & 16.50 & 128.60 \\
The extension of line 2 & 19.50 & 94.37 \\
\hline
\end{tabular}

The analysis on financing mode of first phase project of Wuhan City Rail Transit Line 1. After Wuhan city orbit transportation construction company failed in many multilateral negotiations, it began to explore new ideas for financing capital projects, funds, domestic banks and international lending in1997. Wuhan City government agreed to pay $500{ }^{[2]}$ million yuan (urban construction funds 200 million yuan, the land transfer payments 300 million Yuan), the state-owned asset management companies to invest 480 million yuan, and formed the project capital. After applying the debt of 450 million yuan of special funds, Wuhan city rail construction company negotiated with ICBC, BOC, CCB, bank and other commercial banks, and finally with the National Development Rail Transportation Finally, with the National Development Bank, a loan of 1.05billion-yuan agreement was signed. Some Rail transportation equipment was to be imported from abroad. Manufacturers from Siemens company, Alstom Ltd, Hitachi companies were actively assist foreign government loans, and finally the implementation of the Japan Bank for international cooperation provided by the Japanese government in yen offered a loan of 2.894 billion yen(RMB 220 million yuan) So far, Wuhan City, Metro Line 1 project had been financed for the successful completion of the work.

The total investment for Wuhan City, Metro Line 1, is 2.199 billion yuan, so the final composition of funds for: The project capital 479 million yuan (including urban construction funds 200 million yuan, and the land transfer payments and state-owned assets income 279 million yuan); the debt of 450 million yuan of special funds; National Development Bank loan 1.05 billion yuan; the yen special loans 2.894 billion yuan (equivalent to 220 million yuan) ${ }^{[3]}$. Project financing structure can be shown as below:

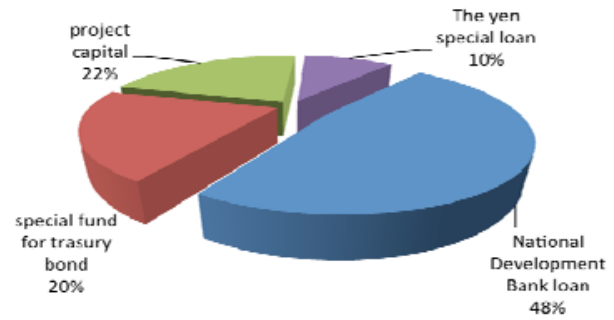

Fig. 1. Project financing structure

In the Project debt funds, bond funds the annual interest rate is $2.55 \%$, repayment period of 15 years; National Development Bank loan interest rate is 5.76\%, repayment period of 15 years; Yen loan interest rate is $0.75 \%$, the repayment period of 40 years. The project of all loans composite interest rate is $4.2 \%$.

Through the above analysis we can see, the project's debt to capital ratio is high, close to $80 \%$ of the total project investment; The sources of funds is not enough diversity, and the State Development Bank loans accounted for a total investment of nearly half of the same. The use of 
foreign capital ratio is not high, only $10 \%$. The category is limited to foreign government aid loans; also it failed to develop exporting credit and other channels of using foreign capital. The funds are funds from national policy. The loan period is long and the loan interest rate is lower than the market interest rate level. The characteristic of the project is really a reflection of the infrastructure project.

An Introduction to the other ways of financing for Wuhan city track traffic. Wuhan Metro Group is the rail transit financing platform built by Wuhan government. In accordance with the relevant provisions of the state rail transit construction, the project capital shall account for more than $40 \%$ of the total investment. This means that, $60 \%$ fund of the construction is needed to rise by Wuhan Metro Group. So Metro Inc. has also been exploring a variety of financing.

Bank loans: In 2007 December, CITIC Bank Wuhan branch and the Wuhan Wuhan Metro Group signed a cooperation agreement, to provide 800 million yuan credit loans ${ }^{[4]}$.

Financing lease: In 2008 November, Wuhan Metro Group and ICBC Finance Leasing Company signed a financing agreement. According to the agreement, part of the equipment and vehicle assets of Wuhan City, the Urban Rail Transit Line 1, should be given to the bank. And within 3 years, 2 billion yuan can be drawn according to the construction needs, and then lease assets from the ICBC above. After paying rent and paying the residual value of assets, it can regain the title. During the term of the lease, rental companies enjoy leasehold ownership of the name, and Wuhan Metro Group is entitled to possession, use of property right and control right. According to the agreement, Wuhan Metro takes "leasing", including "rent" and "after sale leaseback". ICBC leasing funds by stages on the way back to customer service is part of a one-time delivery, and direct hire part is deliver with the Metro Line 2 and line 4 of the construction progress, to the phase of equipment procurement.

The issuance of bonds: In 2013, the national development and Reform Commission officially approved that Wuhan Metro Group could issue 2 billion yuan of corporate bonds and the funds raised by the project of Wuhan city could only be used for the first part of construction of metro line four. This cycle of 2 billion yuan of corporate bonds is 7 years ${ }^{[5]}$. All of the funds are used for construction of the first part of metro line four, which is the first time for Wuhan Metro construction, to insure corporate bonds.

\section{Wuhan rail transit financing mode existing problems}

The financing channel is narrow. Although in recent years financing mode of the city rail transit has been gradually transition to the new diversified financing mode, it doesn't fundamentally eliminate over-reliance on government investment and government subsidies for the construction and operation of city rail traffic. At the end of 2013, the city of Wuhan city investment company raised 154249 million yuan, of which domestic bank loans and loans from international financial institutions amounted to 72367 million yuan, nearly half of the total amount of funds, the project financing amount of 26554 million yuan, accounting for 17\%, the trust funds 16738 million yuan, accounting for $10.85 \%$. At present, private capital almost cannot participate in investment in city infrastructure construction, rarely entering franchising fields. On the one hand it is because of the existence of threshold of franchising, low profitability; on the other hand, there are also the core competitiveness of enterprises, which is not strong for the lack of independent brands, without enough strength. In addition, affected by the national policy environment, the non-public enterprises interests cannot be guaranteed, rules and regulations are not perfect, and supporting policies are not implemented. These factors increase the difficulty of private enterprises involving. While the "franchise", "BOT" and other methods are based on a series of contracts, the contracts, so part of the non-public enterprises is still worried about the government policy changes.

Lack of commercial experience. Although it requires a large investment, has a long payback period, and the balance of payments is not balanced, the project has a long-term stable and steady ticket income. The value of city rail traffic has also led to the property development along. Under the premise of ensuring the safe operation of the subway project, it can increase the income derived by the chain business, advertising, along the property, underground mobile communication and 
video services, smart card service and underground space development and so on many kinds of ways. The huge cash income of the project can be profitable. But in the city rail transit construction in our country, the commercial operation of the concept has not yet formed.

With the rapid development of domestic economy, city rail transit is the key to solving the city traffic problem. Capital has been an important factor of city rail transit development; therefore, it is necessary to study the financing mode of city rail transit. In the process of city rail transit construction, there are similar problems. This paper gives a brief review of Wuhan city track transportation financing, analyzes the existing problems of Wuhan city track transportation financing, in order to provide new ideas for the research of city rail transit financing.

\section{References}

[1] Fenghua Qin. (2009) Wuhan Metro tries the new way of finance lease [J]. The investment of China, 04:80-83+9.

[2] Xiaotian Song,Xiaoyan Zhou.(2014) Optimal stopping method based on the price model of renewal bond - in the case of the line 13 of Wuhan Metro [J]. The financial times, 33:272-273.

[3] Sixin Xie,Shuping Zhao. (2014) The innovation research of the way of financing lease in rail transit based on leverage lease [J]. Railway logistics, 08:32-35.

[4] The official website of Wuhan Metro. (2015.4) http://www.whrt.gov.cn

[5] Weiqi Chi. The analysis of sustainable financing of subway (2015) [J]. Financial community (Academy edition), 01:58+134. 